\title{
Serum levels of testosterone and performance of surgical or immunocastrated beef steers
}

Diego Soares Machado*, Dari Celestino Alves Filho, Flânia Mônego Argenta,

Ivan Luiz Brondani, Ana Paula Machado Martini

\begin{abstract}
The objective of the present study was to evaluate the serum concentration of testosterone and the performance of beef steers submitted to different surgical or immunological castration strategies. Forty- eight Aberdeen Angus calves were randomly distributed in the following treatments: surgical castrated at birth; surgical castrated at weaning; immunocastrated with three doses of Bopriva ${ }^{\circledast}$ vaccine; immunocastrated with four doses of Bopriva ${ }^{\circledast}$ vaccine. The hormonal dosages were performed through ELISA Test by "In vitro" competition. The weighing and body condition score of the animals were determined at the beginning and at the end of each evaluated phase. The completely randomly experimental design was used. Data were submitted to variance analysis by $\mathrm{F}$ test, being the averages compared by Tukey test with $a=0.05$. There was an interaction between treatment and collection date $(P<0.05)$ for the serum levels of testosterone. By occasion of the slaughter, all the animals presented a similar serum concentration of testosterone, characterizing them as castrated. Animals immunological castrated with three doses of Bopriva ${ }^{\circledR}$ presented higher daily average gain and total weight gain on finishing phase than the ones surgical castrated at weaning. The immunological castration shows a viable alternative in relation to surgical castration.
\end{abstract}

Keywords: beef cattle, Bopriva ${ }^{\circledR}$, daily weight gain, finishing, methods of castration

\section{Introduction}

The Brazilian beef cattle production has been intensified over the past years searching for new technologies, aiming the increase of productivity, with a sustainable view for the production system. Among the factors that affect the animal performance, the sexual condition places a major role regarding the Brazilian productive systems, and in many cases it causes impasses in sales between producers and slaughterhouses. In the case of male bovines indicate that these non- castrated animals presents some advantages such as greater corporal development and meat production and better feed conversion. On the other hand, the bovine castration sometimes is used as a fundamental management tool. According to Price et al. (2003) castration offers greater advantages such as better carcass quality, through fat deposition, reduction of aggressive and sexual behavior, that result in an easier and safer handling with the animals, besides reducing the damage to the carcass and increasing the animal welfare.

The most used castration method in Brazil is the surgical castration, however this method is often performed in a wrong way, causing suffer to the animal, without attending the minimal sanitary condition and resulting in productive losses or even causing the death of the animal. 
Nowadays an alternative in our country is the use of temporary immunological castration, characterized by the anti-GnRH immunization, which eliminates the inconvenient of surgical castration. Immunocastration has emerged as an alternative to surgical castration in different animal species, in order to improve animal welfare (Siel et al., 2016).

Several studies were performed testing the efficacy of immunocastration, compared to non- castration in bovines, mainly in feedlot system (Amataiakul-Chantler et al., 2012; Cook et al., 2000; Price et al., 2003) and females bovines (Balet et al., 2014). However in literature the studies are scarce regarding the contrast of the use of immunological castration with the use of surgical castration, on animal performance, in pasture systems (Amataiakul-Chantler et al., 2013).

Based on that, the objective of the present study was to evaluate the serum concentration of testosterone and the performance of beef steers submitted to immunological castration with two protocols or surgical castration in two ages.

\section{Materials and methods}

This work was reviewed and approved by the Ethics Committee on Animal Use the Federal University of Santa Maria, filed under the number 6976300415. The study was performed at Paineiras Farm, located in the city of São Vicente do Sul-RS, with calves from Conceição do Pirajú Farm, located in the city of Manuel Viana - RS. Forty eight Aberdeen Angus male bovines, monitored since birth, standing at the foot of the cow until weaning. The birth of the calves occurred between September 2011 and November 2011. According to the order of birth, the animals were randomly distributed in four treatments, with 12 repetitions: surgical castration at birth; surgical castration at weaning (6 months); immunocastration with three doses of Bopriva ${ }^{\circledast}$ vaccine, at $6^{\text {th }}, 9^{\text {th }}$ and $14^{\text {th }}$ months; immunological castration with four doses of Bopriva $^{\oplus}$, at at $6^{\text {th }}, 7^{\text {th }}, 10^{\text {th }}$ and $15^{\text {th }}$ months of age of the animals. The animals that received three doses of the vaccine were immunized in $04 / 17 / 2012,07 / 17 / 2012$ and $12 / 19 / 2012$, while the ones that received four doses were immunized in 04/17/2012, 05/17/2012, 08/16/2012 and $01 / 16 / 2013$. The surgical castration at weaning occurred in 04/17/2012. At the time of weaning the calves exhibit average age of six months and average weight of $160 \mathrm{~kg}$.

All the Bopriva $^{\circledR}$ vaccinations were applied on the left side of the neck, subcutaneously, in a dosage of $1 \mathrm{~mL}$ per animal, by a veterinarian licensed by the manufacturer of the product. The surgical procedures were performed by a veterinarian. The calves castrated at birth were manually held, while the ones castrated at weaning were held in a squeeze chute. In both groups after finding the testicles at the scrotum, anesthesia was performed using lidocaine at $2 \%$ on the dosage of $6 \mathrm{mg} / \mathrm{Kg}$ of body weight. After this procedure it was performed a skin incision and the testicles were exposed in order to section it with the assistance of a sterilized scalpel in iodine solution, and posteriorly a ligation of the spermatic cords was performed with suture threads. A healing ointment and a repellent were also applied to the incision point and a broad spectrum injectable endectocide based on $1 \%$ of doramectin on the dosage of $1 \mathrm{~mL} / 50 \mathrm{~kg}$ of body weight was applied subcutaneously. The same concentration and dosage of doramectin were administered in the immunocastrated animals. The animals in study remained together and were submitted to the same nutritional, sanitary and environmental conditions from the birth to the slaughter. After weaning, performed on April 17, 2012, the animals remained 30 days in Brachiaria brizantha (cv. MG-5) pasture, being supplemented with protein salt "ad libitum". After this period they were kept in black oat pasture (Avena strigosa Shreb) from May 17 to September 29 of 2012 in the city of Manuel Viana - RS, when they were transfered to São Vicente do Sul - RS and remained there in ryegrass (Lolium multiflorum Lam.) until October 23, 2012. The animal load used during the growing phase was $656.33 \mathrm{~kg}$ body weight/ hectare.

At the finishing phase, from October 23, 2012 to May 22, 2013 the animals remained in two areas of natural pasture, submitted to rotational grazing, where the rotation of the spots occurred every 30 days. On this phase the steers were supplemented with commercial 
ration on the ratio of $1 \%$ of body weight based on dry matter and offered once a day at 08h00. The bromatological composition of the ration is presented on Table 1. In the moment of the slaughter the steers were 19 months old.

No productive and bromatological parameters of the used pastures on the feeding of the animals were determined. The average animal load used in this period was $967.69 \mathrm{~kg}$ body weight/hectare. The mineral supplementation was performed according the farm handling being distributed in covered feeders, besides, the animals had access to water in water troughs or lakes.

Table 1. Bromatological composition of commercial ration.

\begin{tabular}{|c|c|}
\hline Nutrients & Dry Matter \\
\hline Dry Matter ${ }^{1}$ & 903.1 \\
\hline Crude Protein ${ }^{2}$ & 168.0 \\
\hline Ether Extract² & 107.6 \\
\hline Neutral Detergent Fiber ${ }^{2}$ & 176.8 \\
\hline Acid Detergent Fiber ${ }^{2}$ & 158.7 \\
\hline Total Digestible Nutrients ${ }^{2}$ & 767.3 \\
\hline
\end{tabular}

The blood collection were performed in 10 animals of each treatment, being performed on the following dates: 10/23/2012,01/16/2013 and 05/21/2013, always in the same animals. According to the manufacturer, for the animal to be considered immunocastrated it is necessary two application of Bopriva ${ }^{\circledR}$ (dose + reinforcement), with testosterone suppression between seven and fourteen days after the reinforcement and action period, varying according the intervals between dosages. When desired subsequent applications may be performed as in the case of the protocols used in this study. The first collection was performed when the animals presented twelve months old, corresponding to 156 and 66 days after the second and third dose, respectively, in the group that received four doses of Bopriva ${ }^{\circledR}$, and 96 days after the second dose in the group that received three doses of Bopriva ${ }^{\circledR}$. The last collection was performed one day before the slaughter. The collection of the blood sample was performed at tail vein, after the asepsis of the site, being these samples placed in heparinized test tubes. The hormonal dosages were performed through ELISA Test by "In vitro" competition at the Vida Vet Laborator in the city of Botucatu - SP.

The weighing of the animals were performed with the assistance of a calibrated analog scale in 04/17/2012, 05/17/2012, $10 / 23 / 2012$ and $05 / 21 / 2013$, corresponding to three evaluation phases (30 days post- weaning growing and finishing). The average daily gain weight was obtained by the difference between the final and initial weight in each phase, divided by the number of days between the pastures. Preceding each weighing the animals were put in feedlot during the previous night, without water and food, obeying a minimum fasting of 12 hours. The body condition score was obtained by the average of the grades assigned by two trained evaluators, following the Lowman et al. (1973) methodology, where $1=$ very thin and $5=$ very fat.

The completely randomized
experimental design with four treatments and twelve repetitions was used. The collected data were tested regarding the normality by the Shapiro-Wilk test, and adjusts were done when necessary. Posteriorly data were submitted to variance analysis by test $F$ through PROC MIXED for the levels of testosterone and PROC GLM for performance variables. The averages were compared through Tukey test at $5 \%$ of significance level. The mathematic model used in the variance analysis of the variable level of testosterone was the following:

$$
Y_{i j k}=\mu+T_{j}+\varphi_{i}\left(T_{j}\right)+\rho_{k}+\left(T^{*} \rho\right)_{j k}+\varepsilon_{i j k}
$$

where: $Y_{i j k}$ : dependent variables; $\mu$ : average of all observations; $\mathrm{T}_{i}$ : effect of $j$-th treatment; $\varphi_{i}$ : repetition inside the treatment (error $a) ; \rho_{k}$ : effect of $k$-th collection date; $\left(T^{*} \rho\right)$ $j k$ : interaction between the $j$-th treatment and the $k$-th collection date and $\varepsilon_{i j k}$ : residual random error (error b).

For the variables related to performance it was used the following mathematical model for 
variance analysis:

$\mathrm{Y}_{j k}=\mu+\mathrm{T}_{j}+\varepsilon_{j \mathrm{k},}$

where: $Y_{j k}=$ dependent variables; $\mu=$ average of all observations; $T_{j}=$ : effect of $j$-th treatment; $\varepsilon_{j k}=$ residual random error.

\section{Results and discussions}

The results related to the hormonal dosage of testosterone are presented on Table 2. There was a significant interaction between treatment and date of the blood collection
$(P<0.05)$. On the first collection date the immunocastrated animals both with three and with four doses presented greater testosterone dosage, while on the second collection date the animals surgical castrated at weaning presented testosterone dosage similar to the groups immunological castrated with three or four doses on the first collection, being this superior to the other testosterone determinations, independent of the collection date or treatment.

Table 2. Serum levels of testosterone $(\mathrm{ng} / \mathrm{mL})$ of surgical castrated or immunocastrated steers.

\begin{tabular}{lccccc}
\hline \multirow{2}{*}{ Castration } & \multicolumn{3}{c}{ Collection Date } & \multirow{2}{*}{ Mean } & SEM \\
\cline { 2 - 4 } & $10 / 23 / 2012$ & $01 / 16 / 2013$ & $05 / 21 / 2013$ & & \\
\hline At Birth & $1.74^{\mathrm{b}}$ & $4.03^{\mathrm{b}}$ & $1.92^{\mathrm{b}}$ & 2.56 \\
At Weaning & $3.52^{\mathrm{b}}$ & $5.08^{\mathrm{a}}$ & $1.59^{\mathrm{b}}$ & 3.40 & \multirow{2}{*}{0.9552} \\
Immunological with 3 doses & $6.33^{\mathrm{a}}$ & $4.50^{\mathrm{b}}$ & $1.64^{\mathrm{b}}$ & 4.16 & 0.0175 \\
Immunological with 4 doses & $6.59^{\mathrm{a}}$ & $4.02^{\mathrm{b}}$ & $2.35^{\mathrm{b}}$ & 4.32 & \\
Mean & $4.55 \mathrm{~A}$ & $4.41 \mathrm{~A}$ & $1.88 \mathrm{~B}$ & & \\
\hline P value - probability of interaction between treatment and collection date, with a=0.05. SEM - Standard error of mean.
\end{tabular}

The valuesfound for the immunocastrated on the first collection do not match with other data found in literature, because AmataiakulChantler et al. (2012) and Amataiakul-Chantler et al. (2013) verified an effect duration of the vaccine per 105 and 188 days respectively, with intervals between the doses of 42 and 91 days. At the present study this collection occurred 96 days after the reinforcement dosage in the immunocastrated with three doses and 156 and 66 days after the second and third dose in the group submitted to four doses. The authors cited above suggest the expected gamma for the bovine serum concentration of testosterone to be inferior to $5 \mathrm{ng} / \mathrm{ml}$. However Freitas et al. (2015) observed that the concentration of testosterone in immunocastrated steers (receiving the first and second dose 22 and 01 days, respectively before the feedlot), when compared to castrated surgically was similar at baseline, was not maintained until the end of experiment where circulating levels rebounded in immunized.

For the surgically castrated group weaning it appears concentration of $5.08 \mathrm{ng} /$ $\mathrm{ml}$, the second data collection, which would be reported by the mismatch Amataiakul-Chantler et al. (2013).

It is small elevation detected in this study above the limit value may be assigned to the individual variation on the immune response of the individuals cited by Price et al. (2003), wich animals surgical castrated must present only residual levels of testosterone, assigned to a small contribution of the synthesis that occurs in the adrenal glands. These residual levels were highlighted at the present study on the last collection performed at the pre slaughter of the steers.

Cook et al. (2000) working with a vaccine of a similar active principle to this work (anti-GnRH) also detected an interaction for the concentration of testosterone between treatment and period after the active immunization against $\mathrm{GnRH}$ in beef steers. In the study of Cook et al. (2000) 14 days after the application of the second dose the immunized animals obtained a testosterone concentration similar to the control group (non- castrated). However, 42 days after, the immunized ones presented a decrease $(P<0.05)$ in relation to the control group (2.9 vs $7.7 \mathrm{ng} / \mathrm{ml}$ ). Amatayakul-Chantler et al. (2013) evaluating zebu steers raised in pasture verified similarities on the serum concentration of testosterone between the animals immunized with Bopriva ${ }^{\circledR}$ and the ones surgical castrated, fifteen days after the application of the second dose, with values of 0.6 and $0.1 \mathrm{ng} / \mathrm{ml}$, respectively.

Janett et al. (2012) using Bopriva ${ }^{\circledR}$ in the active immunization against $\mathrm{GnRH}$ in prepubescent holstein calves, with three to six 
weeks old, observed that the concentration of testosterone after the reinforcement dosage was significantly inferior to the non immunized calves $(P<0.05)$. These animals remained with inferior levels to $0.5 \mathrm{ng} / \mathrm{ml}$ during at least 22 weeks, making the immunized calves also present a delay in their testicular development and a reduction on the scrotal circumference $(P<0.05)$.

Based on the values presented on

Table 2 it was observed that immunocastration with three doses of Bopriva ${ }^{\circledR}$ vaccine presented similar response to immunocastration with four doses of this vaccine in the suppression of testosterone in all collection dates. This response is very important from the point of view of practical application, because the using of three doses allows to reduce the handling with the animals and the costs with one less dose per animal.

The average data for the performance measures of calves in pasture of Brachiária brizantha, receiving protein salt "ad libitum" is presented on Table 3. There was no significant difference for the analyzed variables in this period $(P>0.05)$. Probably this measurements are justified due the fact that all calves suffered the stressor effect at weaning. However another aggravating factor could occur in the group of the animals surgical castrated at six months due the surgical process to which they were submitted. Nevertheless this fact did not influenced the animals and there was a similarity with the other groups regarding the weight and body condition score after thirty days.

Table 3. Means values, standard error mean (SEM) and probability for weight at weaning and 30 days after, daily average weight gain, total weight gain and initial and final body condition score of calves submitted to surgical or immunological castration.

\begin{tabular}{lcccccc}
\hline \multirow{2}{*}{ Variables } & \multicolumn{4}{c}{ Castration } & \multirow{2}{*}{ SEM } & \multirow{2}{*}{ P value } \\
\cline { 2 - 5 } & \multicolumn{3}{c}{ Surgical } & \multicolumn{2}{c}{ Immunological } & \\
\cline { 2 - 5 } & At birth & At weaning & 3 doses & 4 doses & & \\
\hline Weight at weaning, $\mathrm{kg}$ & 161.04 & 159.62 & 159.08 & 159.79 & 5.02 & 0.9939 \\
Weight 30 days post-weaning, $\mathrm{kg}$ & 164.75 & 165.87 & 164.12 & 163.66 & 5.03 & 0.9907 \\
Daily weight gain, $\mathrm{kg}$ /day & 0.123 & 0.208 & 0.168 & 0.129 & 0.07 & 0.9636 \\
Total weight gain, $\mathrm{kg}$ & 3.70 & 6.25 & 5.04 & 3.87 & 2.20 & 0.9637 \\
Initial body score, points & 2.62 & 2.67 & 2.55 & 2.70 & 0.04 & 0.1262 \\
Final body score, points & 2.66 & 2.69 & 2.64 & 2.72 & 0.03 & 0.3587 \\
\hline Pvalue-probability. & & & & & &
\end{tabular}

Another aspect that contributes for the similarity on the post weaning performance is the equal nutritional handling used with the animals and the health care performed with the castrated calves at weaning, being not observed the occurrence of hemorrhage, myiasis or problems with the cicatrization of the incision for castration, factors that may influence negatively on the performance of the cattle. In steers with twenty months old Amataiakul-Chantler et al. (2013) evaluating the surgical and immunological castration methods with Bopriva ${ }^{\circledR}$ verified that $8.1 \%$ of the animals surgical castrated presented postoperative complications characterized by purulent discharge, myiasis, funiculitis and hemorrhage, fifteen days after castration.

Although less invasive interventions at the time of weaning all the animals received anthelmintic, than those who received the vaccine Bopriva $\AA$, these factors also added that harm the animal welfare and may affect the performance of the animals.

The results obtained in this study corroborate Restle \& Muehlmann (1993) evaluating the weight gain of calves from different genetic groups immediately after castration (17 days) did not verified difference on the performance between castrated and non- castrated $(P>0.05)$, corroborating with the present study.

For Almeida et al. (2010) the surgical castration may be a technique that causes pain to the animal, resulting in a slow growth period and low feed efficiency. However, at the present study no losses were verified on the performance of the animals surgical castrated during the 30 postoperative days, when compared to the others, allowing to infer that the surgery was performed according to the sanitary, handling and animal welfare requirements. 
Data related to the performance of the animals during the growing phase, performed exclusively in winter pasture, are presented on Table 4. The distinct castration protocols used did not affect the development of the animals in this period $(P>0.05)$, with daily average weight gain of $0.694 \mathrm{~kg} /$ day and final average body weight of
$272.95 \mathrm{~kg}$. The initial and final body condition score was similar between the treatments, occurring an average evolution of 0.22 points in the period. In growing phase is very important the animals to have a good development, mainly when the objective is the slaughter in a young age.

Table 4. Means, standard error mean (SEM) and probability for initial and final weight, daily average weight gain, total weight gain and initial and final body condition score in growing phase of calves submitted to surgical or immunological castration.

\begin{tabular}{|c|c|c|c|c|c|c|}
\hline \multirow{3}{*}{ Variables } & \multicolumn{4}{|c|}{ Castration } & \multirow{3}{*}{ SEM } & \multirow{3}{*}{$P$ value } \\
\hline & \multicolumn{2}{|c|}{ Surgical } & \multicolumn{2}{|c|}{ Immunological } & & \\
\hline & At birth & At weaning & 3 doses & 4 doses & & \\
\hline Initial weight, kg & 164.75 & 165.87 & 164.12 & 163.66 & 5.03 & 0.9907 \\
\hline Final weight, kg & 279.54 & 270.16 & 274.04 & 268.08 & 6.74 & 0.6456 \\
\hline Daily weight gain, kg/day & 0.735 & 0.668 & 0.704 & 0.669 & 0.03 & 0.4007 \\
\hline Total weight gain, $\mathrm{kg}$ & 114.79 & 104.29 & 109.91 & 104.41 & 5.01 & 0.3996 \\
\hline Initial body score, points & 2.66 & 2.69 & 2.64 & 2.72 & 0.03 & 0.3587 \\
\hline Final body score, points & 2.93 & 2.88 & 2.90 & 2.90 & 0.02 & 0.5195 \\
\hline
\end{tabular}

The similarity verified on the development of the animals of this study is related to the equal nutritional handling used, which may have been limiting for a higher individual performance of the animals, by the offered forage availability. The immunocastrated group with three doses of vaccine had the definitive dosage of castration two months after the weaning, remaining under a possible effect of androgenic hormones for a longer time, according to reported previously. However this fact did not provided differences on the animal performance on this phase, having as main causes for this result, the fact that two months may be considered a short period during the life cycle of a bovine and also due to the prepubertal phase of the animals.

The results was confirmed by other studies that also did not observed androgenic effect of testosterone for the non- castrated animals when compared to the ones immunocastrated during the prepubescent age (Aïssat et al., 2002.; Cook et al., 2000; Janett et al., 2012).

The observed performance at present study was similar to the one verified by Vaz et al. (2011) working with calves with the same age and same roughage basis, in which these authors obtained a daily weight gain of $0.722 \mathrm{~kg} /$ day. Aïssat et al. (2002) working with Angus calves and Angus crossbred fed with alfalfa hay and triticale "ad libitum" at the growing phase did not obtained difference on the performance of the calves surgical or immunological castrated, presenting values of 0.710 and $0.770 \mathrm{~kg} /$ day.

Data related to the steers performance during finishing phase are showed on Table 5. Although there was no significant difference for the weight at the beginning and at the end of finishing phase, the variables, daily average weight gain and total weight gain were affected by the treatments $(P<0.05)$.

The steers immunocastrated with three doses of Bopriva ${ }^{\circledR}$ presented greater performance in this characteristics when compared to the ones surgical castrated at weaning (6 months old).

The initial expectancy was that the immunocastration with three doses of Bopriva ${ }^{\circledR}$ would provide a superior performance on the growing and/or finishing phase of the animals of this group, in relation to the others, because the animals would remain non- castrated for a longer period of time.

However this hypothesis do not support on the obtained result for the weight gain on the finishing phase, once the difference existed only in relation to the castrated animals at weaning by the surgical method. Besides, the serum testosterone level on the final phase of the study was similar among the groups (Table 2). It is worth noting however it should be noted that cattle with greater weight gain in the finishing phase, 
Table 5. Means, standard error mean (SEM) and probability for initial and final weight, daily average weight gain, total weight gain and initial and final body condition score in finishing phase of steers submitted to surgical or immunological castration.

\begin{tabular}{|c|c|c|c|c|c|c|}
\hline \multirow{3}{*}{ Variables } & \multicolumn{4}{|c|}{ Castration } & \multirow{3}{*}{ SEM } & \multirow{3}{*}{$P$ value } \\
\hline & \multicolumn{2}{|c|}{ Surgical } & \multicolumn{2}{|c|}{ Immunological } & & \\
\hline & At birth & At weaning & 3 doses & 4 doses & & \\
\hline Initial weight, kg & 279.54 & 270.16 & 274.04 & 268.08 & 6.74 & 0.6456 \\
\hline Final weight, kg & 379.54 & 353.83 & 382.88 & 372.50 & 10.14 & 0.1945 \\
\hline Daily weight gain, kg/day & $0.478^{a b}$ & $0.400^{b}$ & $0.520^{a}$ & $0.499 a b$ & 0.03 & 0.0362 \\
\hline Total weight gain, kg & $100.00^{a b}$ & $83.66^{b}$ & $108.83^{a}$ & $104.41^{\mathrm{ab}}$ & 6.22 & 0.0359 \\
\hline Initial body score, points & 2.93 & 2.88 & 2.90 & 2.90 & 0.02 & 0.5195 \\
\hline Final body score, points & 3.18 & 3.16 & 3.16 & 3.19 & 0.03 & 0.7639 \\
\hline
\end{tabular}

present this performance for converting food into lean meat more efficiently and have good muscle: bone ratio, with lower fat proportions (Rodriguez et al., 2014).

This is confirmed for the present data, as immunocastrated steers with three doses of Bopriva $^{\circledR}$ had higher muscle: bone surgically castrated at weaning (Machado, 2015), a result which is related to the allocation of nutrient intake for the deposition of different tissues.

Among the studies that compare surgical castration to immunological castration, Aïssat et al. (2002) did not detected difference in the daily average weight gain during finishing in feedlot with values of 1.75 vs $1.61 \mathrm{~kg} / \mathrm{day}$, for immunocastrated and surgical castrated, respectively. Geary et al. (2011) also did not observed difference between surgical and immunological castration on performance of crossbred steers Angus x Hereford. In Brazil Amataiakul-Chantler et al. (2013) evaluating the effect of Bopriva ${ }^{\circledR}$ compared to surgical castration under the performance of Bos indicus bovines aged 20 months old in Panicum maximum pasture found a daily weight gain superior for the immunocastrated (0.79 vs $0.75 \mathrm{~kg} /$ day). Moreira et al. (2015) evaluated daily gain and final weight in tropical pasture with supplementation of steers not castrated or castrated under the two methods used in this study, found that the castrated animals, regardless of the method had similar performance.

At the present study, even without significant difference, the steers immunocastrated with three doses of Bopriva ${ }^{\circledR}$ were numerically 7.58\% heavier than the ones castrated at weaning. This result may reflect in an expressive difference on remuneration at the moment of commercialization. Regarding the age for surgical castration there was a similarity on the performance of the steers castrated at birth and at weaning $(P>0.05)$.

There was no effect of method nor castration age on the body condition score, with average value of 3.17 points, at the end of finishing phase, when the animals were sent to be slaughtered, in a scale from 1 to 5 . This value, according to the classification of Lowman et al. (1973) represents that occurred a complete muscle deposition, but the back fat would be still insufficient what could make the commercialization unviable. Vaz et al. (2011) evaluating Braford steers in similar age, finished in tropical pasture obtained an average body condition score of 4.34 points, classifying the animals as fat, with carcass with degree of fatness consistent to the market requirements. In the study of Aguinaga et al. (2006), steers slaughtered at fourteen months it was obtained body conditions between 3.1 and 3.6 points, reaching subcutaneous fat thickness between 2.25 and $2.77 \mathrm{~mm}$, however it was not reached the minimum degree of fatness required by the slaughter- houses. Low values of body condition score may be attributed to the fact that the animals are in the growing phase and the diet does not provide high weight gain, reflecting in a low body fat deposition (Vaz et al., 2011). Although the productive and bromatological parameters of the pasture were not determined, the natural pasture used at the present study in finishing phase, associated to supplementation probably did not reached the energetic requirements for an adequate fat deposition.

According data observed that the performance and body condition of the animals 
since the birth until the pre-slaughter were not affected neither by the method nor by the age of castration.

This inference including all the evaluation phase of the experiment is justified by the fact that it allows an appreciation of the results in all productive process. Thus, allowing researches, technicians and beef cattle farmers to evaluate the adoption or not of a technology or protocol according to the presented results.

According to Peres-Linares et al. (2016), immunocastration of males bovines with Bopriva ${ }^{\circledR}$ represents an attractive alternative for today's livestock industry, since considering animal welfare is less traumatic than traditional castration, and decreased the serum testosterone levels, making the animal handling easier.

It is important to mention that the results obtained through field researches must be carefully observed through a systemic vision, because in some cases numerical differences may reflect on the profitability of the system, in large scale productions.

\section{Conclusion}

Serum testosterone concentration, prior to slaughter, was similar between the groups studied.

Immunocastration is a viable alternative to surgical castration. Immunocastration with three doses is recommended because it allows reduction of cost and management.

\section{Acknowledgements}

To Zoetis for giving the vaccines to perform the immunocastration, as well as all medications and vaccines to perform the sanitary control of the animals. Also to have been responsible for the costs with the analysis for determination of testosterone concentration and with the concentrated feed provided in finishing.

To the owners of the animals and farms for the possibility to perform the study and also to CAPES for the grant of the master's degree scholarship of the first author.

\section{References}

Aguinaga, A.A.Q.; Carvalho, P.C.F.; Anghinoni, I.; Santos, D.T.; Freitas, F.K.; Lopes, M.T. 2006. Produção de novilhos superprecoces em pastagem de Aveia e Azevém submetida a diferentes alturas de manejo. Revista Brasileira de Zootecnia, 35: 1756-1773.

Aïssat, D.; Sosa, J.M.; Avila, D.M.; Bertrand, K.P.; Reeves, J.J. 2002 Endocrine, growth, and carcass characteristics of bulls immunized against luteinizing hormone-releasing hormone fusion proteins. Journal of Animal Science, 80: 22092213.

Almeida, K.B.; Silveira, A.C.; Oliveira, V.A. 2010. Orquiectomia em bovinos. Enciclopédia Biosfera, 6: 1-14.

Amataiakul-Chantler, S.; Jackson, J.A.; Stegner, J.; King, V.; Rubio, L.M.S.; Howard, R.; Lopez, E.; Walker, J. 2012. Immunocastration of Bos indicus $x$ Brown Swiss bulls in feedlot with gonadotropinreleasing hormone vaccine Bopriva provides improved performance and meat quality. Journal of Animal Science, 90: 3718-3728.

Amataiakul-Chantler, S.; Hoe, F.; Jackson, J.A.; Roça, R.O.; Stegner, J.; King, V.; Howard, R.; Lopez, E.; Walker, J. 2013. Effects on performance and carcass and meat quality attributes following immunocastration with the gonadotropin releasing factor vaccine Bopriva or surgical castration of Bos indicus bulls raised on pasture in Brazil. Meat Science, 96: 78-84.

Balet, L.; Janett, F.; Hüsler, J.; Piechotta, M.; Howard, R.; Amataiakul-Chantler, S.; Steiner, A.; Hirsbrunner, G. 2016. Immunization against gonadotropin-releasing hormone in dairy cattle: antibody titers, ovarian function, hormonal levels, and reversibility. Journal of Dairy Science, 97:2193-2203.

Cook R.B., Popp J.D., Kastelic J.P., Robbins S., Harland R. 2000. The effects of active immunization against GnRH on testicular development, feedlot performance, and carcass characteristics of beef bulls. Journal of Animal Science, 78: 27782783.

Freitas, V.M.; Leão, K.M.; Neto, F.R.A.; Marques, T.C.; Ferreira, R.M.; Garcia, L.L.F.; Oliveira, E.B. 2015. Effects of surgical castration, immunocastration and homeopathy on the performance, carcass characteristics and behaviour of feedlot-finished crossbred bulls. Semina: Ciências Agrárias, 36:1725-1734.

Geary, T.W.; Wells, K.J.; Avila, D.M.; Avila, J.; Conforti, V.A.; Mclean, D.J.; Roberts, A.J.; Waterman, R.W.; Reeves, J.J. 2011. Effects of immunization against luteinizing hormone releasing hormone and treatment with trenbolone acetate on reproductive function of beef bulls and steers. Journal of Animal Science, 89: 2086-2095.

Janett, F.; Gerig, T.; Tschuor, A.C.; Amataiakul- 
Chantler, S.; Walker, J.; Howard, R.; Piechotta, M.; Bollwein, H.; Hartnack, S.; Thun, R. 2012. Effect of vaccination against gonadotropin-releasing factor (GnRF) with Bopriva ${ }^{\circledR}$ in the prepubertal bull calf. Animal Reproduction Science, 131: 7280 .

Lowman, B.G.; Scott, N. and Somerville, S. 1973. Condition scoring beef cattle. Edinburgh: East of Scotland College of Agriculture, 8p.

Machado, D. 2015. Uso da imunocastração como alternativa à castração cirúrgica na produção de novilhos para abate. 99p. (Dissertação M.sc.) - Universidade Federal de Santa Maria, Santa Maria - RS, Brasil.

Moreira, P.S.A.; LourençO, F.J.; Lima, C.C.; Faria, F.F.; El Farra, A.; Romero, N.B. 2015. Desempenho produtivo e características de carcaça de bovinos Nelore submetidos a diferentes métodos de castração. Revista Brasileira de Ciências Agrárias, 10: 570-575.

Peres-Linares, C.; Bolado-Sarabia, L.; FigueroaSaavedra, F.; Barreras-Serrano, A.; SánchezLópez, L.; Tamayo-Sosa, A.R.; Godina, A.A.; RíosRincón, F.; Garcia, L.A.; Gallegos, E. 2016. Effect of immunocastration with Bopriva on carcass characteristics and meat quality of feedlot Holstein bulls. Meat Science, 123: 45-49.

Price, E.O.; Adams, T.E.; Huxsoll, C.C.; Borgwardt, R.E. 2003. Aggressive behavior is reduced in bulls actively immunized against gonadotropinreleasing hormone. Journal of Animal Science, 81: 411-415.

Restle, J. and Muehlmann, L. 1993. Ganho de peso de terneiros de diferentes grupos genéticos no período imediatamente após a castração. Semina: Ciências Agrárias, 14: 9-11.

Rodriguez, J.; Unruh, J.; Villarreal, M.; Murillo, O.; Rojas, S.; Camacho, J.; Jaeger, J.; Reinhardt, C. 2014. Carcass and meat quality characteristics of Brahman cross bulls and steers finished on tropical pastures in Costa Rica. Meat Science, 96: 1340-1344.

Siel, D.; Vidal, S.; Sevilla, R.; Paredes, R.; Carvallo, F.; Lapierre, L.; Maino, M.; Pérez, O.; Sáenz, L. 2016. Effectiveness of an immunocastration vaccine formulation to reduce the gonadal function in female and male mice by Th1/Th2 immune response. Theriogenology, 86: 1589-1598.

Vaz, R.Z.; Lobato, J.F.P.; Pascoal, L.L. 2011. Desenvolvimento de bezerros de corte desmamados aos 80 ou 152 dias até os $15-16$ meses de idade. Revista Brasileira de Zootecnia, 40: 221-229.

Zanella, R.; Zanella, E.L.; Reeves, J.J.; Hernandez,
J.; Motta, A.C.; Avila, D. 2009. Características testiculares de touros imunizados com vacina anti-hormônio liberador do hormônio luteinizante. Pesquisa Agropecuária Brasileira, 44: 1359-1363. 